$2^{\circ}$ seminário de pesquisa do programa de pós-graduação em design

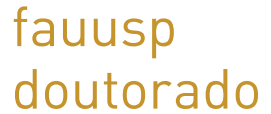

\section{Arquitetura em processo: Matrizes conceituais entre a arte e a arquitetura na obra da Zaha Hadid}

\author{
Architecture in process: \\ Conceptual matrices between art and architecture \\ in the work of Zaha Hadid
}

LIMA, A. R. R.

Graduada em Arquitetura e Urbanismo pela Universidade Mackenzie (1994). Mestrado em Design e Arquitetura pela FAU USP (2013). Cursa o Doutorado em Design e Arquitetura pela FAU USP (2018). Atua na área de design de sistemas industrializados. Graduated in Architecture and Urbanism from Mackenzie University (1994). She has Master's degree in Design from FAU USP (2013) and is currently doing a Doctorate in Design at FAU USP (2018). She has experience in industrialized systems design.

PERRONE, R. A. C.

Professor Associado no curso de Arquitetura e Urbanismo da Universidade de São

Paulo e da Universidade Prebisteriana Mackenzie.

Tem interesse de pesquisa em: projeto de arquitetura, design, ensino de arquitetura e processo de projeto.

Associate Professor of Architecture and Urbanism at the University of São Paulo and at the Mackenzie Presbyterian University. His research interests include: architecture project; design; architectural teaching; design process

\section{Adriana Ricciardi Rodrigues Lima, Rafael Antonio Cunha Perrone}

A tese de doutorado direto tem como objeto de estudo o desenvolvimento e processo de projeto a partir da obra da arquiteta Zaha Hadid. 0 objeto de conhecimento é composto pelo desenvolvimento de superfícies arquitetônicas e relações com as artes contemporâneas e explicitação das novas possibilidades e capacidades dos sistemas representacionais, operacionais e/ou generativos utilizados no processo de produção de projetos de arquitetura. A pesquisa é composta por várias camadas de estudo como método de abordagem pelo qual o objeto de estudo tornará explicito o objeto de conhecimento que se propõe elucidar na tese.

As hipóteses que permeiam a tese são decorrentes da leitura da produção arquitetônica da Zaha Hadid caracterizada como formulação de uma arquitetura experimental. A hipótese que se coloca é a seguinte: na contemporaneidade a formulação de arquiteturas experimentais se baseia em vários fatores que vão além da inovação formal, os quais consideram a arquitetura como uma sequência de desenvolvimentos conceituais e projetuais que se iniciam na reformulação ou criação de um sistema de projeção próprio - representacional, operativo e/ou generativo característico da experimentação.
The doctoral thesis aims to study the development and design process of the work of the architect Zaha Hadid. The object of knowledge is composed by the development of architectural surfaces and relations with the contemporary arts and by the new possibilities and capacities of the representational, operational and generative systems used in the process of producing architecture projects. The research is comprised of several layers of study as a method of approach by which the object of study will make explicit the object of knowledge proposed to be elucidated in the thesis. The hypotheses that permeate the thesis are derived from the reading of the architectural production of Zaha Hadid characterized as the formulation of an experimental architecture. The hypothesis is as follows: in the contemporary world the formulation of experimental architectures is based on several factors that go beyond formal innovation, which consider architecture as a sequence of conceptual and design developments that begin in the reformulation or creation of a new projective system representational, operative and generative - characteristic of the experimentation.

Keywords: Zaha Hadid; Experimental architecture; Projective systems;

Design processes
Palavras-chave: Zaha Hadid; Arquitetura experimental; Sistemas projetivos; Processos de projeto contato

adrianarrlausp.br racperroneagmail.com lattes

http://lattes.cnpq.br/ 5444300591935367 realização

ppgdesign_fauusp
5 dezembro 2018

cidade universitária, são paulo, sp 